\title{
Identifying risk issues and research advancements in supply chain risk management
}

\author{
Ou Tang and Nurmaya Musa
}

\section{Linköping University Post Print}

\section{Tweet}

N.B.: When citing this work, cite the original article.

Original Publication:

Ou Tang and Nurmaya Musa, Identifying risk issues and research advancements in supply chain risk management, 2011, International Journal of Production Economics, (133), 1, 25-34.

http://dx.doi.org/10.1016/j.ijpe.2010.06.013

Copyright: Elsevier

http://www.elsevier.com/

Postprint available at: Linköping University Electronic Press

http://urn.kb.se/resolve?urn=urn:nbn:se:liu:diva-69766 
Identifying risk issues and research advancements in supply chain risk management Ou Tang ${ }^{1}$ and S. Nurmaya Musa ${ }^{1,2, *}$

${ }^{1}$ Department of Management and Engineering, Linköping University, SE-581 83 Linköping, Sweden

${ }^{2}$ Department of Engineering Design and Manufacture, University of Malaya, 50603 Kuala Lumpur, Malaysia

\begin{abstract}
The purpose of this paper is to investigate the research development in supply chain risk management (SCRM), which has shown an increasing global attention in recent years. Literature survey and citation/co-citation analysis are used to fulfil the research task. Literature survey has undertaken a thorough search of articles on selected journals relevant to supply chain operations management. Meanwhile, citation/co-citation analysis uses Web of Sciences database to disclose SCRM development between 1995 and 2009. Both approaches show similar trends of rising publications over the past 15 years. This review has piloted us to identify and classify potential risk associated with different flows, namely material, cash and information flows. Consequently, we identify some research gaps. Even though there is a pressing need and awareness of SCRM from industrial aspect, quantitative models in the field is relatively lacking and information flow risk has received less attention. It is also interesting to observe the evolutions and advancements of SCRM discipline. One finding is that the intellectual structure of the field made statistically significant increase during 2000-2005 and evolved from passively reacting to vague general issues of disruptions towards more proactively managing supply chain risk from system perspectives.
\end{abstract}

Keywords: Supply Chain, Risk Management, Citation/Co-citation Analysis

*Corresponding author

*Nurmaya Musa: nurmaya.musa@liu.se phone: +46-13-285785

Ou Tang: ou.tang@liu.se

phone: +46-13-281773

Dept. of Management and Engineering, Linköping University, SE 58183 Linköping, Sweden Fax: +46-13-281101 


\section{Introduction}

Production in the early years was simple, with single flow of products moving from raw material suppliers, to manufacturers and then to markets. Nowadays, shorter product lifecycle and increasing demand among all have led to a complicated supply chain. Due to cost pressure and competitive advantages, companies are adopting globalization and outsourcing strategies. This also requires an extended supply chain network, hence increases the nodes in the system. In addition, many companies have introduced lean production concepts which intend to remove "wastes" from a supply chain, for instance, by reducing number of suppliers. This helps in smoothing the operations but it would also create problems if unexpected events happen in a supply chain. The rising use of internet helps supply network in sharing information visibility (Christopher and Lee, 2004; Lee, 2002, 2004; Narayanan and Raman, 2004). It is indubitable that the emerging uses of enterprise resource planning (ERP) solutions such as Oracle and SAP have cut down the information transaction time and reduced the incidents of inaccuracy and redundancy. Vast assistance from these systems has however exposed to another consequence, namely information disruption.

All above changes have inevitably increased the importance of supply chain risk management (SCRM). One typical example is Ericsson's crisis in 2000. Since a single-source policy was used, a fire accident in its chips supplier immediately disrupted the material supply. Ericsson's loss was estimated to reach USD 400 million in the T28 model (Norrman and Jansson, 2004). In June 2008, Volvo Cars reported 28\% reduction of sales compared with the same period in previous year, with the biggest loss in its SUVs for about 50\%. Fredrik Arp, CEO of Volvo Cars stated that "the weak dollar reduces the revenue and it will further reduce the opportunities for $R \& D$ ". Another example is the Taiwan earthquake in December 2006, which caused breakage in undersea cables and slowed down internet. One immediate effect is a prolonged waiting time of containers in the Shanghai sea port in China, since all claim 
procedures rely on information systems. Nature disaster, terrorist attack, labor strike, accidents can all be the causes for supply chain disruption and delay (Berger et al., 2004; Christopher and Lee, 2004; LaLonde, 2004; Norrman and Jansson, 2004; Poirier et al., 2007; Quinn, 2006; Tang, 2006a). The above examples show that any material, financial or information risk could create problems in a supply chain. Any hiccup transpired within the supply chain will cause delay and even disruption (Buzacott, 1971). Disruption does not only halt the supply chain operations, but without preparation and precaution, it takes time for the affected system to recover (Sheffi and Rice, 2005; Hendricks and Singhal, 2005

The above background provides the motivation to investigate the current trend and issues in SCRM. Our main objective is through literature review to i) define the important risk issues and mitigation techniques in SCRM; ii) understand the research trend both from industrial and academic perspectives; and iii) identify the possible research gaps and opportunities in the field.

\section{Research process}

This study is based on the review of existing literature using two approaches; literature survey as well as basic bibliometric method of citation and co-citation analysis. Before we present the details of these two approaches, we need clarify some definitions.

\subsection{Risk definition}

In SCRM literature, there exist various definitions of risk. In particular, it is not clear to distinguish risk and uncertainty in supply chain operations. Risk sometimes is interpreted as unreliable and uncertain resources creating supply chain interruption, whereas uncertainty can be explained as matching risk between supply and demand in supply chain processes. We believe that two dimensions are important in discussing risk: the outcome of risk impact and expectation of risk sources. As in most literature, we also agree that risk issue is associated with negative consequences of impact (Christopher and Lee, 2004, Paulson, 2005, Spekman 
and Davis, 2005, Wagner and Bode, 2006). However, the second dimension, expectation of risk is difficult to define. Should risk event be expected (as supplier has quality deficiencies experienced by Robert Bosch GmbH, Wagner and Bode, 2006) or unexpected (such as wars, strikes or terrorist attacks, Christopher and Lee, 2004; Kleindorfer and Saad, 2005; Quinn, 2006)? Furthermore, could the expectation be described by probability and how? These questions have been debated for centuries and these are the reasons for having vague definitions of risk.

In our opinion, a better definition of supply chain risk should refer to i) events with small probability but may occur abruptly, and ii) these events bring substantial negative consequences to the system. Consequently, we follow the SCRM definition from Tang (2006a) "the management of supply chain risk through coordination or collaboration among the supply chain partners so as to ensure profitability and continuity".

\subsection{Literature survey}

Literature survey aims at understanding the important issues and mitigation techniques in SCRM, including the current status and the development tendency in the area. Thus we attempt to make a thorough search of articles in related publication databases. Articles are selected from business review journals, operations management journals, as well as management science or operations research (MS/OR) type of journals. The operations management journals can be either conceptual modeling or quantitative modeling orientated, in order to understand the practical needs as well as the theoretical development in SCRM. In addition, journal is selected only if it is related to supply chain management. The list of journal is given in Table 1 .

Based on the description of definitions in previous section, we use search keywords supply chain, supply chain risk or supply chain risk management together with risk or uncertainty. 
After obtaining these articles, we use the criteria "high impact and low probability risk" to filter the most relevant ones. Finally we have shortlisted and reviewed 138 articles between the years of 1995 and the first half of 2008 .

Table 1: List of journals reviewed

I: Business / Management Review

California Management Review

Decision Sciences

Harvard Business Review

Interfaces

MIT Sloan Management Review

Supply Chain Management Review

\section{II: Operations management journals}

International Journal of Logistics Management

International Journal of Logistics: Research and Application

International Journal of Operations \& Production Management

International Journal of Physical Distribution \& Logistics Management

Journal of Operations Management

Production and Operations Management

Supply Chain Management: An International Journal

\section{III: MS/OR type journals}

European Journal of Operational Research

International Journal of Production Economics

International Journal of Production Research

Journal of the Operational Research Society

Management Science

Omega

Operations Research

Production Planning \& Control

\subsection{Citation and co-citation study}

The study result in literature survey is subject to the articles chosen within limited number of journals selected. Thus we propose citation/co-citation analysis to comprehend our findings. Citation/co-citation analysis is a quantitative method and it adopts bibliometric approach to investigate the structures and evolution of research in a particular discipline, in this case, SCRM. In particular, citation analysis is used to obtain some statistics data relating to gathered publications. Meanwhile, co-citation approach serves very well for the purpose of defining the intellectual structures in the area (Pilkington and Meredith, 2009). 
Citation/co-citation analysis has its limitation in terms of the search method. In our case, articles are gathered based on searching abstract and keywords, which are provided by either authors or journal editors. However, the keywords used and abstract presented might not always aligned with our needs, since authors often have own reasons and styles in highlighting their articles. Thus, we could gather some articles irrelevant to the study, or we may have missed some relevant articles. In order to reduce this problem, we limit our search on Web of Sciences (WoS) database. Even though WoS has its limitation on the number of journals in the database (as compared to Scopus for instance), it is very selective and covers only peer-reviewed journals with high impact factors. As a result, WoS often includes highcited articles, which are more rigid in keywords assignment and abstract presentation.

We then use the same search keywords on WoS database and attempt to disclose SCRM development during 1995 to 2009 . The time horizon has been divided into three segments as T1 (1995 - 1999), T2 (2000 - 2004), and T3 (2005 - 2009). In total 236 articles have been obtained and examined by keywords co-occurrence. (cf. Pilkington \& Meredith (2009) for details on citation/co-citation analysis).

We have to note that the two search methods end with different number of articles, since we have not performed any journal refinement in WoS search. Thus some journals which do not have supply chain management as a main scope are included as well. Also WoS search has been performed up till December 2009 as compared to June 2008 in literature survey. Finally the applications BibExcel and Pajek are used for multidimensional scaling, cluster analysis and factor analysis on co-citations approach.

\subsection{Supply chain operations framework}

Supply chain is a complicated production system. One important change in managing supply chain is the emphasis on integrating activities into key supply chain processes instead of 
individual functions. With regard of SCRM, managerial aspect may not be the same when considering the inbound and outbound sides. For instance, when we discuss the risk in terms of supplier selection, a major concern is to sustain the flow of raw material. However, on the demand side, financial risk (such as customer's possibility of bankruptcy) may appear more important.

However, there was no clear evidence of flows interlinking as well as integrating activities in previous SCRM studies, possibility due to its complexity. Therefore, in this paper, we will identify the flows in the forms of material, financial and information. In addition, we will analyze the system process of source (supply), make (production) and deliver (demand), based on Supply Chain Operations Reference (SCOR) Model. We define material flow as physical movement of products from suppliers to customers. Letters of credit, timely payment of bills, bankruptcy, payment schedules, credit terms and suppliers' contract fall under the category of financial flows. Finally, information flow is used to keep all supply chain elements updated and hence provides resources for decision making. Examples of information flow are order status, order delivery and inventory status, among others. Similar thoughts appear in Chopra and Sodhi (2004), Johnson (2001) and Spekman and Davis (2004), in which the authors identify risks in form of other flows.

\section{Results}

\subsection{An overview of literature survey}

This section presents an overview of literature survey. The number of publication on each year is indicated in Figure 1. Main issues discussed during year 1995 until 1999 include financial risk management and operations strategies such as adoption of lean concept and early supplier involvement (Table 2). Between years 2000 and 2003, the number of articles in SCRM slowly increases. Main issues vary from operation plans to relationship of supply chain partners. In the same time period, we also note the emerging of studies on information 
technology and information flow. Meantime, we also note a rising discussion on globalization risk associating with political and cultural practices.

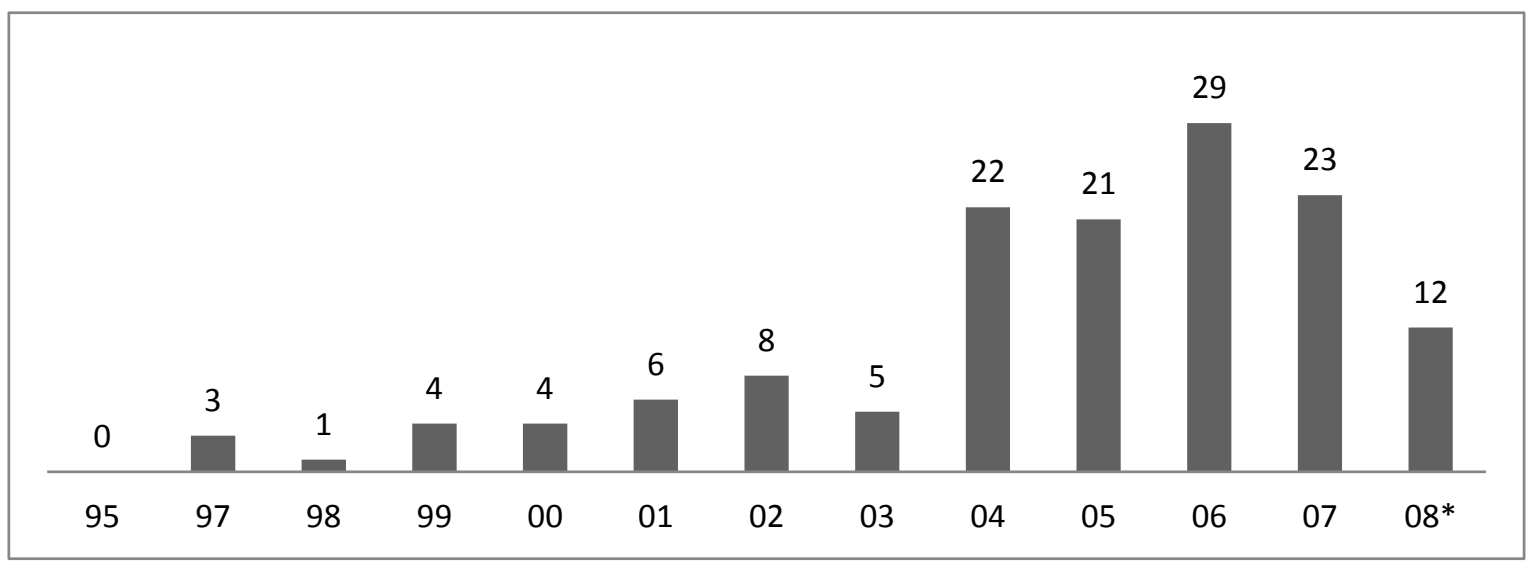

Figure 1: Number of articles by year of publication (* up to June 2008)

A dramatic increase of publications starts in 2004, from which SCRM exhibits a steady rising of interest from academic researchers and practitioners. Challenges and opportunities of outsourcing to low cost countries are the favorite discussion topics. Others include supply chain partner relationship, supply chain environmental, economy and political issues, and growth of information sharing and security. Several studies on financial risk are also noted. A summary of supply chain risk studies obtained from literature reviews is given in Table 2.

Table 2: Main issues discussed over the years by literature reviews findings

\begin{tabular}{|l|l|l|}
\hline $\mathbf{1 9 9 5} \mathbf{1 9 9 9}$ & $\mathbf{2 0 0 0} \mathbf{2 0 0 4}$ & $\mathbf{2 0 0 5} \mathbf{2 0 0 8}$ \\
\hline Operation strategies & Operation strategies & Financial risk management \\
Financial risk management & Supply chain partners relationship & Operation strategies \\
& Information management & $\begin{array}{l}\text { Environmental } \\
\text { Information management } \\
\text { Political \&cultural practices }\end{array}$ \\
& Environmental & $\begin{array}{l}\text { Outsourcing to low cost } \\
\text { countries }\end{array}$ \\
\hline
\end{tabular}


Our study also shows that main SCRM articles are found in the business or management review journals (cf. Table 1) with $41 \%$. The next group is operation management journals of $34 \%$, among which most are conceptual models. After year 2000, more quantitative orientated articles were published. However, the number of articles compared to qualitative orientated ones is still considerably small. This indicates a growing awareness of SCRM in industry, but still there is a lacking of quantitative models for system analysis and decision supporting.

\subsection{Major risk issues}

In this section we summarize the major risk issues according to our literature survey. For a detail description of various risks in supply chain, we refer to Tang (2006a), although the author presents a different study aspect. We further identify risks in material, information and financial flows, which are necessary in operating a supply chain no matter how simple or extended it is.

\subsubsection{Material flow risk We first investigate the material flow which involves physical} movement within and between supply chain elements. We further categorize perspectives of risk events into the stages of source, make and deliver. The results are summarized in Table 3. Source involves inquiring physical products or services. Typical risk issues are single sourcing risk, sourcing flexibility risk, supplier selection/outsourcing, supply product monitoring/quality and supply capacity. Ericsson's inability of reacting to a supplier's fire accident is the consequence of single sourcing risk (Peck et al., 2003). On the other hand, flexible supplier sourcing has benefited firms in having alternatives in the case of capacity constraint or hazardous disruption, but it may, as Kamrad and Siddique (2004) and LaLonde (2000) note, still bring a hidden cost and managerial difficulties when switching suppliers. Supplier selection/outsourcing increase complexity of the supply process. While outsourcing in a way reduces manufacturing costs and improves responsiveness, on the other hand, it has increased the variation of choices and concerns, hence selecting the right supplier has become 
difficult. At the very least, supplier selection should consider supplier reliability, country risk, transport reliability and supplier's supplier reliability (Levary, 2007). When a company decides to outsource globally, it is most likely cost-driven. However, not long, the unseen cost of outsourcing has eventually unveiled, such as various taxes, fluctuating currency exchange rates, import/export duties, increasing transportation costs and suppliers audit costs (Crone, 2006; Fitzgerald, 2005; Kremic et al., 2006; Murphy, 2007; Stalk, 2006). Operational performance such as transportation lead time could be another concern. In addition, lacking of supply product monitoring creates quality associated problems such as product safety and contamination (Fitzgerald, 2005). Supply capacity is another form of risk, if supply chain does not have an early supplier involvement in new product development (Khan et al., 2008).

The major issues at make stage involve product and process design risk, production capacity risk, and operational disruption. First, product and process design risk occurs with inability to cope with changes, in particular associated with new product development stage (Khan et al., 2008) and product launch activity (Handfield et al., 1999). The issue is significant since it involves a big sum of capital spent in positioning products in the market. Production capacity risk refers to technological, skills and quality capacities (Handfield et al., 1999). Finally, operational disruption often happens due to operational contingencies, natural disasters and political instability including terrorism (Kleindorfer and Saad, 2005).

On the deliver side, we have main risk issues as demand volatility/seasonality, balance of unmet demand and excess inventory. These issues are all affected by the forecasting difficulties due to seasonality, volatility of fads, new product adoptions, and short product life (Johnson, 2001; Wong and Hvolby 2007). In addition, due to rapid technology evolvement and customer demand changes, excess inventory may expose the obsolete risk, cf. the wellknown case of inventory write-off in Cisco (Narayanan \& Raman, 2004). 
In the above discussion, we focus on individual flow. We need to acknowledge that when discussing risk, these flows are related and interconnected and therefore cases of one flow disruption obstructing the others are common. From the supply chain scopes, logistics, price volatility of commodity and alternative energy, environment degradation and awareness, political risk, cultural and ethics, and supply chain partners relationship are other risk issues need to be concerned.

Table 3: Material flow risk and mitigation techniques

\begin{tabular}{|c|c|c|}
\hline Risk elements & Qualitative Solution & Quantitative Solution \\
\hline \multicolumn{3}{|l|}{ Material Flow Risk } \\
\hline \multicolumn{3}{|l|}{ Source } \\
\hline Single Sourcing risk & $\begin{array}{l}\text { - Multiple sourcing (Norrman \& Jansson, } \\
\text { 2004) } \\
\text { - Alternative sourcing in and out of home } \\
\text { country (Fitzgerald, 2005) } \\
\text { - Resilience supply chain (Christopher \& } \\
\text { Peck, 2004; Peck et al., 2003) }\end{array}$ & \\
\hline $\begin{array}{l}\text { Sourcing flexibility } \\
\text { risk }\end{array}$ & $\begin{array}{l}\text { - Resilience supply chain (Christopher \& } \\
\text { Peck, 2004) }\end{array}$ & $\begin{array}{l}\text { - Real option model for flexible } \\
\text { sourcing (Kamrad \& Siddique, } \\
\text { 2004) } \\
\text { - Multivariate analysis DSS (Kremic } \\
\text { et al., 2006) } \\
\text { - Procurement contract model } \\
\text { (Martinez-de-Albeniz \& Simchi- } \\
\text { Levi, 2005) }\end{array}$ \\
\hline $\begin{array}{l}\text { Supply product } \\
\text { monitoring / Quality }\end{array}$ & $\begin{array}{l}\text { - Alternative sourcing in and out of home } \\
\text { country (Fitzgerald, 2005) }\end{array}$ & \\
\hline Supply capacity & $\begin{array}{l}\text { - Alternative sourcing in and out of home } \\
\text { country (Fitzgerald, 2005) } \\
\text { - Outsourcing (Johnson, 2001) } \\
\text { - Build a flexible web of partners (Johnson, } \\
\text { 2001) } \\
\text { - Early supplier involvement (Handfield et } \\
\text { al., 1999) }\end{array}$ & \\
\hline $\begin{array}{ll}\text { Supplier } & \text { selection } \\
\text { /outsourcing } & \end{array}$ & $\begin{array}{l}\text { - Alternative sourcing in and out of home } \\
\text { country (Fitzgerald, 2005) } \\
\text { - Avoid outsourcing/off-shoring: in-house / } \\
\text { regional manufacturing (Crone, 2006; } \\
\text { Stalk, 2006) }\end{array}$ & $\begin{array}{l}\text { - Decision-tree based optimization } \\
\text { model (Berger et al., 2004) } \\
\text { - Foreign suppliers supply risk } \\
\text { ranking model (Levary, 2007) } \\
\text { - Selection model based on cost, } \\
\text { quality, responsiveness, strategic } \\
\text { issue and operating constraint } \\
\text { (Kirkwoord et al., 2005) } \\
\text { - Incentive conflicts } \\
\text { coordinating contracts model } \\
\text { (Agrell et al., 2004) } \\
\text { - Simulated-based decision support } \\
\text { system (DSS) model for } \\
\text { collaboration level selection }\end{array}$ \\
\hline
\end{tabular}




\begin{tabular}{|c|c|c|}
\hline Risk elements & Qualitative Solution & Quantitative Solution \\
\hline & & $\begin{array}{l}\text { (Cigolini \& Rossi, 2006) } \\
\text { - Multivariate analysis DSS (Kremic } \\
\text { et al., 2006) }\end{array}$ \\
\hline \multicolumn{3}{|l|}{ Make } \\
\hline $\begin{array}{l}\text { Product and process } \\
\text { design risk }\end{array}$ & $\begin{array}{l}\text { - ESI (Handfield et al., 1999; Khan et al., } \\
\text { 2008; Peck, 2005) }\end{array}$ & \\
\hline $\begin{array}{l}\text { Production capacity } \\
\text { risk }\end{array}$ & $\begin{array}{l}\text { - ESI (Handfield et al., 1999; Khan et al., } \\
\text { 2008; Peck, 2005) } \\
\text { • Early warning system (Bovet, 2006) }\end{array}$ & $\begin{array}{l}\text { - Options contract model (Fang \& } \\
\text { Whinston, 2007) }\end{array}$ \\
\hline Operational disruption & $\begin{array}{l}\text { - ESI (Handfield et al., 1999; Khan et al., } \\
\text { 2008; Peck, 2005) } \\
\text { - Alternative sourcing in and out of home } \\
\text { country (Fitzgerald, 2005) } \\
\text { - Supply chain design (Kleindorfer \& Saad, } \\
\text { 2005) } \\
\text { - Operational hedging (Cudahy et al., 2008) }\end{array}$ & $\begin{array}{l}\text { - Optimization model (Tomlin, } \\
\text { 2006) }\end{array}$ \\
\hline \multicolumn{3}{|c|}{ r } \\
\hline $\begin{array}{l}\text { Demand } \quad \text { volatility/ } \\
\text { Seasonality }\end{array}$ & $\begin{array}{l}\text { - Postponement strategy (Bovet, 2006) } \\
\text { - Adopting / improvising information } \\
\text { technology (Lee, 2002, 2007) } \\
\text { - Mixed model (Lee, 2002, 2007) } \\
\text { - Aligning interest (Lee, 2004) } \\
\text { - Licensing (Johnson, 2001) } \\
\text { - Increase number of channels (Johnson, } \\
\text { 2001) } \\
\text { - Build longer life products i.e. rolling mix } \\
\text { (Johnson, 2001) } \\
\text { - Lean manufacturing (Abernathy, 2000; } \\
\text { Geary et al., 2002) } \\
\text { - Operational hedging (Cudahy et al., 2008) } \\
\text { - Application of best practices (Geary et al., } \\
\text { 2002) }\end{array}$ & $\begin{array}{l}\text { - Postponement model (Tang, } \\
\text { 2006b) } \\
\text { - OPP relocating opportunities and } \\
\text { QR simulation (Wong \& Hvolby, } \\
\text { 2007) } \\
\text { - Robust economic order quantity } \\
\text { (EOQ) model (Sounderpandian, et } \\
\text { al., 2008; Yu, 1997) } \\
\text { - Optimization model for optimal } \\
\text { operating policy (Li et al., 2001; } \\
\text { Wu, 2006)) } \\
\text { - Linear dynamic system model } \\
\text { (Zhang, 2006) } \\
\text { - Incentive } \\
\text { coordinating conflicts } \\
\text { (Agrell et al., 2004) } \\
\text { - Two-stage stochastic model using } \\
\text { real option and financial options } \\
\text { (Ding et al., 2007) } \\
\text { - Options contract model (Fang and } \\
\text { Whinston, 2007) } \\
\text { - Multi stage stochastic model (Goh } \\
\text { et al., 2007) } \\
\text { - Equilibrium modeling to counter } \\
\text { supply and demand risk (Nagurney } \\
\text { et al., 2005) }\end{array}$ \\
\hline $\begin{array}{l}\text { Balance of unmet } \\
\text { demand and excess } \\
\text { inventory }\end{array}$ & $\begin{array}{l}\text { - Lean manufacturing (Abernathy, 2000; } \\
\text { Geary et al., 2002) } \\
\text { - Reduce inventory holding (Jüttner, 2005) } \\
\text { - Propose application of "demand-at-risk" } \\
\text { (Sodhi, 2005) } \\
\text { - Propose application of "inventory-at-risk" } \\
\text { (Sodhi, 2005) }\end{array}$ & $\begin{array}{l}\text { - Options contract model (Fang \& } \\
\text { Whinston, 2007) } \\
\text { - Improvise contract with aligned } \\
\text { incentives (Narayanan \& Raman, } \\
\text { 2004) } \\
\text { - Robust economic order quantity } \\
\text { (EOQ) model (Yu, 1997) } \\
\text { - Value-at-Risk model (Tapiero, } \\
\text { 2005, 2007) }\end{array}$ \\
\hline \multicolumn{3}{|l|}{ Supply chain scope } \\
\hline Logistics & $\begin{array}{l}\text { - Reduce transport content:- reduce the } \\
\text { cumulative length of SC (Crone, 2006) } \\
\text { - Use transportation more efficiently:- } \\
\text { more-efficient consolidated shipments or }\end{array}$ & - Financial modeling (Hauser, 2003) \\
\hline
\end{tabular}




\begin{tabular}{|c|c|c|}
\hline Risk elements & Qualitative Solution & Quantitative Solution \\
\hline & use third party provider (Crone, 2006) & \\
\hline $\begin{array}{l}\text { Price volatility of } \\
\text { commodity/alternative } \\
\text { energy }\end{array}$ & - Operational hedging (Cudahy et al., 2008) & \\
\hline $\begin{array}{l}\text { Environment } \\
\text { degradation } \\
\text { awareness }\end{array}$ & $\begin{array}{l}\text { - Supplier initiatives evaluation (Cousins et } \\
\text { al., 2004) } \\
\text { - Invest in environmental protection effort } \\
\text { (Economy \& Lieberthal, 2007) }\end{array}$ & \\
\hline Political risk & $\begin{array}{l}\text { - Operational hedging (Cudahy et al., 2008; } \\
\text { Johnson, 2001) }\end{array}$ & \\
\hline \multicolumn{3}{|l|}{ Cultural and ethics } \\
\hline $\begin{array}{l}\text { Supply chain partners } \\
\text { relationship }\end{array}$ & $\begin{array}{l}\text { - Discount contract module (Cachon, 2004) } \\
\text { - Improvise contract with aligned incentives } \\
\text { (Narayanan \& Raman, 2004) } \\
\text { - E-business loyalty (Reichheld \& Shefter, } \\
\text { 2000) }\end{array}$ & $\begin{array}{l}\text { - Simulated-based decision support } \\
\text { system (DSS) for collaboration } \\
\text { level selection (Cigolini \& Rossi, } \\
\text { 2006) }\end{array}$ \\
\hline
\end{tabular}

3.2.2 Financial flow risk Financial flow risk involves the inability to settle payments and improper investment. The common risks are exchange rate risk, price and cost risk, financial strength of supply chain partners and financial handling/practice. The results are illustrated in Table 4.

Table 4: Financial flow risk and mitigation techniques

\begin{tabular}{|c|c|c|}
\hline Risk elements & Qualitative Solution & Quantitative Solution \\
\hline \multicolumn{3}{|l|}{ Financial Flow Risk } \\
\hline Exchange rate risk & - Operational hedging (Johnson, 2001) & $\begin{array}{l}\text { - Flexible sourcing model (Kouvelis, } \\
\text { 1999) } \\
\text { - Two-stage stochastic model using } \\
\text { real option and financial options } \\
\text { (Ding et al., 2007) } \\
\text { - Multi stage stochastic model (Goh et } \\
\text { al., 2007) } \\
\text { - Optimization model for optimal } \\
\text { operating policy (Li et al., 2001) }\end{array}$ \\
\hline Price and cost risk & $\begin{array}{l}\text { - Framework to enable SC driven profit } \\
\text { growth (Bovet, 2006) } \\
\text { - Avoid low cost country (Stalk, 2006) } \\
\text { - Real options application (van Putten \& } \\
\text { MacMillan, 2004) }\end{array}$ & \\
\hline $\begin{array}{l}\text { Financial strength of } \\
\text { supply chain partners }\end{array}$ & $\begin{array}{l}\text { - Early-payment programs (Hartley- } \\
\text { Urquhart, 2006) } \\
\text { - Stock-price benchmarking (Hendricks \& } \\
\text { Singhal, 2005) }\end{array}$ & \\
\hline $\begin{array}{l}\text { Financial handling } \\
\text { and practice }\end{array}$ & $\begin{array}{l}\text { - Early-payment programs } \quad \text { (Hartley- } \\
\text { Urquhart, 2006) }\end{array}$ & \\
\hline
\end{tabular}


Research on exchange rate risk can be found at Li et al. (2001), Carr (1999), Goh et al. (2007) and Kouvelis (1999), among others. With a global supply chain as a study scope, exchange rate has a major influence on firm's after tax profit, supplier selection, market development and other operation decisions. Price and cost risk can be strongly attached with exchange rate, but its fluctuation may also be caused by scarcity of raw materials (Papadakis, 2006). Hendricks and Singhal (2005) study financial flow vulnerability and long term effect of supply chain disruptions with focus on financial strength of supply chain partners. Their empirical study also shows this type of risk can be evaluated based on the evidence of increasing equity risk, financial leverage and asset risk. The vulnerability of financial strength of a supply chain member, may easily affect the entire supply chain network (Peck et al., 2003; Tang, 2006b; Hartley-Urquhart, 2006), referring Asia's financial crisis in 1997 as case in point. Finally Hartley-Urquhart (2006) and Kerr (2006) discuss the risk arising from financial handling and practice. For instance, an increasing velocity and quantity of payment should complicate the financial flow and need urgent attention. Lack of control and visibility of procure-to-pay process may cause alleged illegal collection of excess vendor markdown. 3.2.3 Information flow risk Value adding activities in a supply chain is often triggered by information flows such as demand, inventory status, order fulfillment, product and process design changes and capacity status. One may also look at information flow as the bonding agent between material flow and financial flow. Here we obtain issues such as information accuracy, information system security and disruption, intellectual property and information outsourcing risk (cf. Table 5).

The risk of information accuracy may cause by information accessibility, information efficiency and data accuracy (Lee, 2002, 2004; Geary et al., 2002; Raman et al., 2001; Giermanski, 2000; Bradley, 2001; Faisal et al., 2007). Inaccurate information should further affect decision making in supply chain. The threats of information system security and 
disruption could be internally due to ill-manage system, or externally by hackers and nature disaster (Faisal et al., 2007). The information system risk can also be considered at application, organizational and inter-organizational levels (Finch, 2004). Intellectual property risk is associated with increasing information flow in supply chain network and in the meantime inability of protecting information sharing, for instance trade secret exposure (Barry, 2004). Information outsourcing allows company to focus on the core-competence. However, it also increases risk of opportunism of vendors, information security apprehension, hidden costs, loss of control, service debasement, disagreements, disputes and litigation, and poaching (Faisal et al., 2007).

Table 5: Information flow risk and mitigation techniques

\begin{tabular}{|c|c|c|}
\hline Risk elements & Qualitative Solution & Quantitative Solution \\
\hline \multicolumn{3}{|c|}{ Information Flow Risk } \\
\hline Information accuracy & $\begin{array}{l}\text { - Aligning interest (Lee, 2004) } \\
\text { - Implementation of CPFR, ECR, VMI } \\
\text { concepts (Faisal et al., 2007) } \\
\text { - Chaos theory (Bradley, 2001) } \\
\text { - Application of best practices (Geary et al., } \\
\text { 2002) } \\
\text { - Improvise inventory data handling and } \\
\text { policies (Raman et al., 2001) }\end{array}$ & \\
\hline $\begin{array}{lr}\text { Information } & \text { system } \\
\text { security } & \text { and } \\
\text { disruption } & \end{array}$ & $\begin{array}{l}\text { - Contingency planning (Finch, 2004) } \\
\text { - Assess and manage IS of the firm and SC } \\
\text { partners (Finch, 2004) }\end{array}$ & \\
\hline \multicolumn{3}{|l|}{ Intellectual property } \\
\hline $\begin{array}{l}\text { Information } \\
\text { outsourcing }\end{array}$ & $\begin{array}{l}\text { - 'Value-added' outsourcing, 'Co-sourcing' and } \\
\text { create 'spin-off' with vendors (Faisal et al., } \\
\text { 2007) } \\
\text { - Improve visibility (Christopher \& Lee, 2004) }\end{array}$ & \\
\hline
\end{tabular}

\subsection{Results of citation and co-citation studies}

Citation analysis shows similar trends of rising publications during the three time segments, based on both core articles (articles obtained from database search) and cited references (Figure 2). A significant increase occurs in 2007. More interestingly, the cited references show steady increase in 1990s with a dramatic rise in 2000. This believes resulted from the arising vulnerability issues, such as the Asian economic crisis in 1997. 


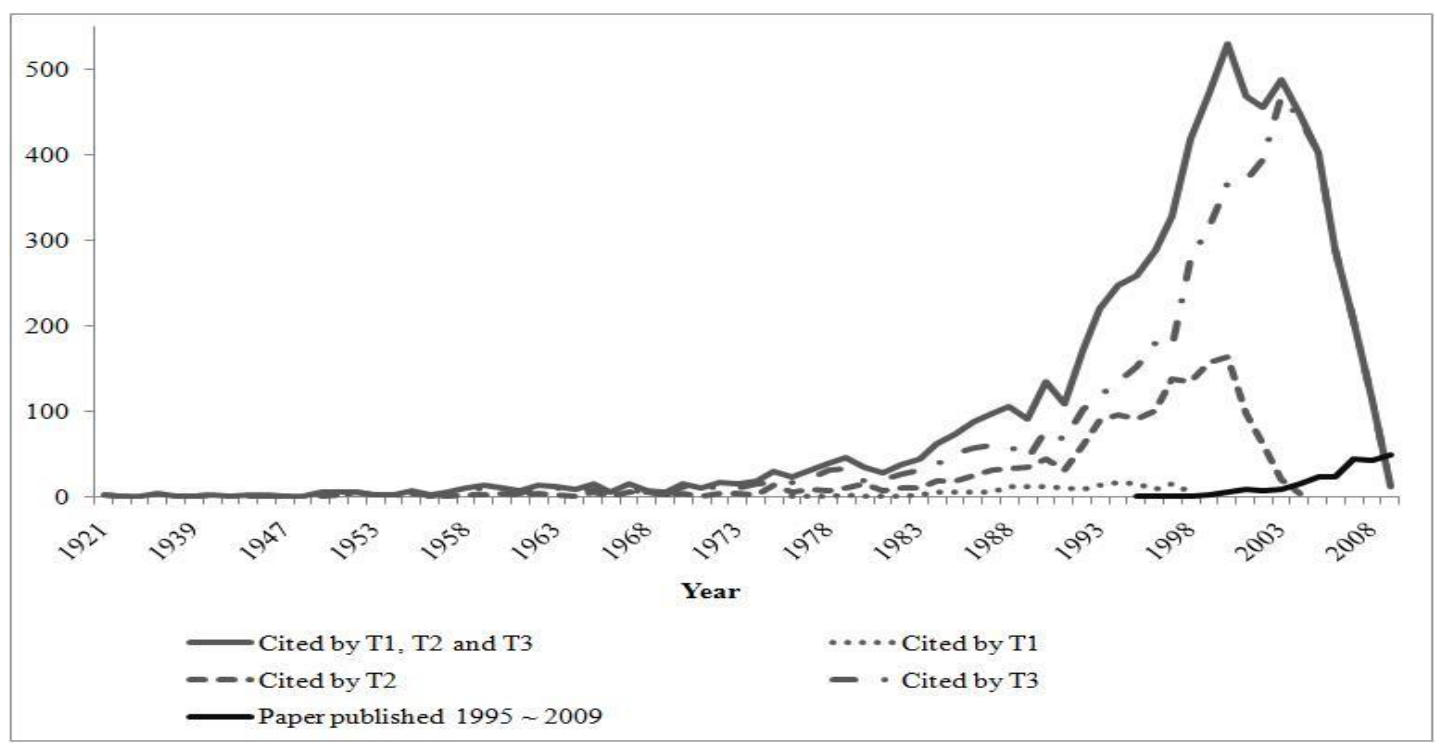

Figure 2: Development of core articles and cited articles for SCRM in $1995 \sim 2009$

By using the co-citation analysis, we note the emergency of various clusters between three time segments T1, T2 and T3 with number of cluster 3,11 and 9, respectively. The cluster is defined from the keywords co-occurrence analysis. The results indicate that the intellectual structure of SCRM field has made statistically significant increase in T2 and research has evolved from vague general issues of supply chain disruptions towards more specific yet global perspectives of risk. This can be seen in Figures 3, 4 and 5. In the time segment T1 (1995-1999), distinct areas such as operation management (T1-1), inventory theory (T1-2) and lean/product introduction (T1-3) are the only clusters, which are also studied independently. In the time segment T2 (2000-2004), more clusters appear and some weak links have been established between clusters for risk issues (cf. Figure 4). In the time segment T3 (2005-2009), the SCRM discipline shows further development, since the clusters are more integrated and many exhibit a strong connection with integrated SCRM (T3-1) and liability management (T3-3) as well as inventory management (T3-5). 

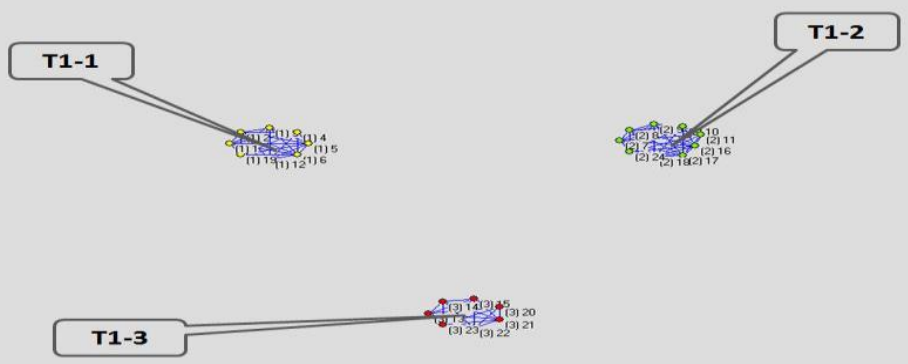

Figure 3: Keywords co-occurrence cluster for $\mathrm{T} 1$

(T1-1:operation management; T1-2:inventory theory; T1-3:Lean, product introduction)



Figure 4: Keywords co-occurrence cluster for T2

(T2-1:innovation, logistics; T2-2:interfaces, EDI; T2-3:production planning \& management; T2-4: production planning system; T2-5:organizational; T2-6:management strategies; T2-7:policies; T28:MRP; T2-9:facility planning; T2-10:contract; T2-11: cost)

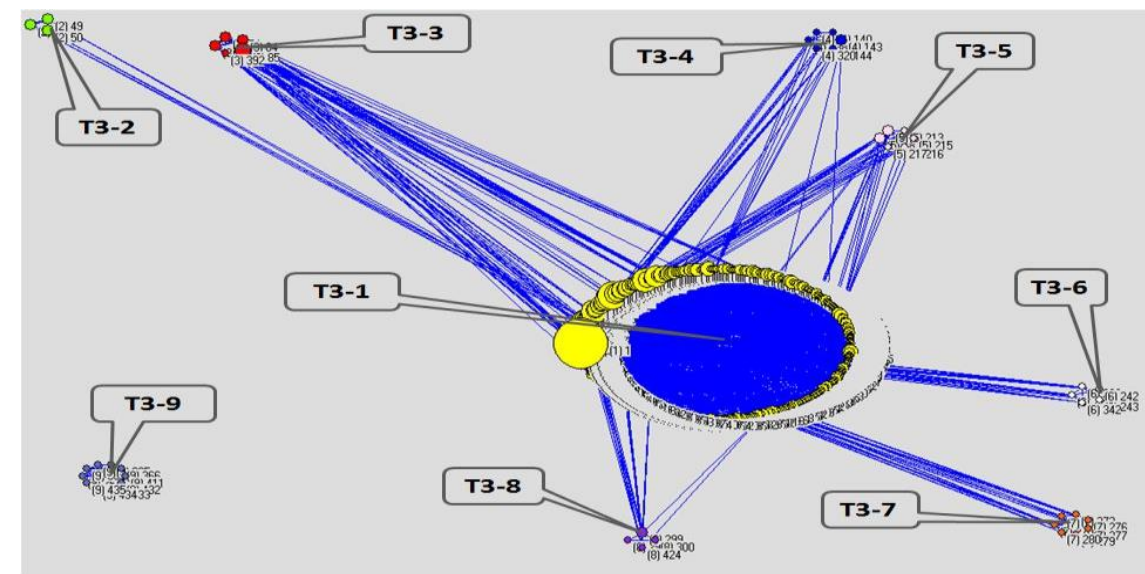

Figure 5: Keywords co-occurrence cluster for T3

(T3-1:integrated SCRM; T3-2:inventory models; T3-3:liability management; T3-4:human factors; T35: inventory management; T3-6:earnings \& returns; T3-7:agricultural; T3-8:financial risk; T3-9:Gen. Motor case) 
Table 6: Main issues discussed over the years by co-citation analysis

\begin{tabular}{|l|l|l|}
\hline T1 (1995 1999) & T2(2000 2004) & T3(2005 2009) \\
\hline Performance & Innovation & Management \\
Successes & Industry & Systems \\
Power & Logistics & Model \\
Entry & EDI & Performance \\
Strategies & Model & Networks \\
Order & Management & Information \\
Quantity discount & Information & Product \\
Inventory & Organizations & Integration \\
Management & Interface & Design \\
Coordination & Perceptions & Products \\
\hline
\end{tabular}

With co-citation analysis, we also obtain the top ten most popular keywords (top vertices) used in articles (Table 6). The keyword performance has been lately replaced by Innovation and then management. By observing the change of these keywords, we can see the changing attitude of researchers and practitioners towards SCRM. We note that in T1, popular vertices such as performance and successes are associated with the reaction of risk impacts. In T2, technologies (vertices such as innovation, logistics and EDI) are adopted to prevent risk, whereas in $\mathrm{T} 3$ attention has been shifted to management and also from system perspective. The study of SCRM thus has been changed from passively reacting to risk events to actively managing them, and the focus has been changed from local to system aspect. In addition, Table 6 illustrates growing importance of information, cf. the appearance and rank of the vertex information as in the second and third columns.

\subsection{Remarks}

Dawning of this century shows opportunities of applying modern supply chain concepts in SCRM, according to our literature survey. Enterprise Risk Management studies the variance between business strategies outcome and objectives (Dickinson, 2001; Chapman, 2006) whereas Business Contingency Planning prepares oneself for possibility of future emergency or disruption (Rice and Caniato, 2003; Sheffi 2005; Carter and Rogers, 2008). There are also 
rising discussions on Business Vulnerability (Sheffi 2005; Svensson 2002; Peck et al., 2003) which to some extent triggers the realization of Supply Chain Resilient (Rice and Caniato 2003; Sheffi and Rice, 2005; Christopher and Peck, 2004; Carter and Rogers, 2008). These concepts revolve more on proactive risk responses rather than on preventive risk actions. The literature survey brings a consistent result as from the co-citation cluster analysis.

Nevertheless, the literatures on SCRM are mainly based on qualitative approach and only a small fraction falls under the category of quantitative approach. According to the literature survey, the majority of studies are conceptual models, overview and exploratory reviews, empirical studies (industrial cases, interviews and surveys). Among 138 papers, $78 \%$ belong to this category. Many review articles cover some perspectives (but with different dimensions compared to this paper) of supply chain risk. Frameworks have also been developed to explore the risk issues in supply chains and further propose mitigation techniques. A big portion of articles cover the sourcing issue with or without the combination of other supply chain elements. The empirical studies also have a strong focus on sourcing policies. In addition most discussed and implemented methods are associated with material flow disruption risk, this can be illustrated as large number of references in Table 3 whereas relatively small numbers in Tables 4 and 5.

Only a quarter of articles in literature propose quantitative models in risk analysis, which again can be seen in Tables 3, 4 and 5. In particular, quantitative methods are missing in information flow analysis. In the literature survey, typical quantitative approaches are optimization, multivariate analysis, options contracts model, stochastic programming and simulation, real option. 


\section{Discussions and conclusions}

In this paper, we have reviewed recent literature relevant to SCRM. The research tendency of the field has been investigated. Empirical evidences have shown severe consequences after supply chain disruptions, such as lose of profit, damage of market share, etc. This leads to a general increasing interest in SCRM. The need of having an integrated view of SCRM has been growing strong, according to the co-citation analysis. SCRM definitely needs an integration of knowledge from multiple researches disciplinary. In addition, the future analysis tools should aim at proactively managing supply chain risk.

Major risk issues and risk mitigation techniques have been investigated based on material, cash and information flows. The summary is presented in Tables 3, 4 and 5, which further indicate some research gaps. Most literature still focuses on material flow issues in risk management, in particular with supplier selection. Some efforts have been made to integrate material and cash flows by adapting financial option theory. According to our literature survey, there is a lacking of models in analyzing risk associated with information flows, possibly due to missing of appropriate modeling techniques in this area.

The study also indicates a larger number of publications in business journals. In addition, the existing literature includes mainly descriptive and conceptual models rather than quantitative models. Hence, there is a pressing need (or awareness) of studying risk management issues from industrial practice, whereas there is a missing gap and potential in developing quantitative models to make hard decisions in managing the risk.

Regarding the possible modeling techniques and approaches in this research area, we propose the following potential methods in developing quantitative models for risk management.

Robust planning: This planning approach aims at exploring the uncertainty inherent in a supply chain, and developing optimization decisions which provide more predictable results. For instance at strategic decision level, how to design a supply chain so that key performance 
indicators have stable outcomes for different production scenarios. At operational level, we should investigate which control policy needs less modification with a changing production environment. Also it is of interests to investigate the institutional aspects of supply chain, namely, with updated conditions and institutional constraints, how the previous supply chain decisions can be modified. This involves not only the robustness of a decision, but also the (re)computational efficiency of the optimization algorithms. One advantage of this approach is due to its proactive planning capability.

Revenue management: As we have mentioned in this paper, most supply chain risk study focus on supply side. But with a supply disruption, we can still use different pricing policies to redistribute customer's demand for different products so as to mitigate the supply risk. Such a policy was used by Dell when they faced a chips supply problem in Taiwan. In this case, revenue management can be used to develop pricing policy and investigate how to allocate and relocate capacity to different market segments when supply chain encounters a disruption.

Agency theory: supply chain disruption often creates asymmetric and incomplete information. In addition, goal confliction, adverse selection, moral hazard can be frequent phenomenon in supply chain which further damages the supply chain performance. Risk sharing is often suggested to reduce the vulnerability of a supply chain, in both cases of normal operation and disruption. Different incentive policies are also used in practice (for instance cash donation by LG to its customer during the China earthquake 2008) to recover the cash flows in a supply chain during crisis. Agency theory can therefore be appropriate to understand interrelationship between supply chains, and thus maintain a system perspective in management.

Option theory: Option nowadays has been used as a standard tool to buffer financial risks in a company. Integrating real and financial options should definitely enhance the performance of a supply chain, in particularly in a global production environment. This should concern not 
only strategic/tactic decisions such as supplier selection, supplier switch, but also operational decisions such as speculation inventory, invoicing currency etc. Thus it provides chances to integrated different flows in supply chain.

System dynamics: This modeling approach is often used to understand and analyze a supply chain and its inherent control policies. A typical example is applying such method to investigate the bullwhip effect in a supply chain. It is important to understand the disperse mechanism after a disruption "shock" is received in a supply chain. How long it will take to translate disruption information to other nodes of a supply chain? How long it will take to recover from a shock with different control policies? Moreover, a supply chain may overreact and build excess capacity during a risk event. Control theory and system dynamics approach could be very promising in modeling risk information flows.

Reverse logistics: Reverse logistics has captured substantial attention in recent years due to environment legislation and economic incentives. In auto industry, remanufacturing return cores has been used as an alternative to supply service market. Can we use the similar business concept and use return products as a backup (of materials) in a supply chain? This should provide a chance to enhance supply reliability and in the meantime reduce capital tied up.

Understanding comprehensively what risk is, where risk exists, and how to mitigate risk definitely exhibits an additional research challenge in supply chain management. However, with an increasing awareness of risk management issues, both from industrial and academic aspects, we believe that developing risk management models should improve a supply chain competence in the new business environment and definitely it is a promising and important research area in operations management. 


\section{References}

1. Abernathy, F.H., Dunlop, J.T., Hammond, J.H. and Weil, D., (2000). Control Your Inventory in a World of Lean Retailing. Harvard Business Review, Nov/Dec 2000, Vol. 78 Issue 6, 169-176.

2. Agrell, P.J., Lindroth, R. and Norrman, A., (2004). Risk, information and incentives in telecom supply chains. International Journal of Production Economics, 90 (2004) 1-16.

3. Barry, J., (2004). Supply chain risk in an uncertain global supply chain environment. International Journal of Physical Distribution \& Logistics Management, 34/9 (2004), 695-697.

4. Berger, P.D., Gerstenfeld, A. and Zeng, A.Z., (2004). How many suppliers are best? A decision-analysis approach. Omega, 32 (2004) 9- 15.

5. Bovet, D., (2006). The Self-Funding Supply Chain. Supply Chain Management Review, Jul/Aug2006, Vol. 10 Issue 5, 9-10.

6. Bradley, P., (2001). The Certainty of Uncertainty. Supply Chain Management Review, Mar/Apr2001, Vol. 5 Issue 2, 105-106.

7. Buzacott, J.A., (1971). The Role of Inventory in Flow-line Production Systems. International Journal of Production Research, 9(4) 425-436.

8. Cachon, G.P., (2004). The Allocation of Inventory Risk in a Supply Chain: Push, Pull, and Advance-Purchase Discount Contracts. Management Science, Vol. 50, No. 2, February 2004, 222 238.

9. Carr, N.G., (1999). Managing in the Euro Zone. Harvard Business Review, Jan/Feb 1999, Vol. 77 Issue 1, p47-48.

10. Carter, C.R. and Rogers, D.S., (2008). A framework of sustainable supply chain management: moving toward new theory. International Journal of Physical Distribution \& Logistics Management, Vol. 38 No. 5, 2008, 360-387.

11. Chopra, S. and Sodhi, M.S., (2004). Managing Risk To Avoid Supply-Chain Breakdown. MIT Sloan Management Review, Fall 2004, Vol. 46 Issue 1, p53-62.

12. Christopher, M. and Lee, H., (2004). Mitigating supply chain risk through improved confidence. International Journal of Physical Distribution \& Logistics Management, Vol. 34 No. 5, 2004, 388-396.

13. Christopher, M. and Peck, H., (2004). Building the Resilient Supply Chain. International Journal of Logistics Management, Vol. 15 No. 2, 2004, 1-13.

14. Cigolini, R. and Rossi, T., (2006). A note on supply risk and inventory outsourcing. Production Planning \& Control, Vol. 17, No. 4, June 2006, 424-437. 
15. Cousins, P.D., Lamming, R.C. and Bowen, F., (2004). The role of risk in environment-related supplier initiatives. International Journal of Operations \& Production Management, Vol. 24 No. 6, 2004, 554-565.

16. Crone, M., (2006). Are Global Supply Chains too Risky?: A Practitioner's Perspective. Supply Chain Management Review, May/Jun2006, Vol. 10 Issue 4, p28-35.

17. Cudahy, G., Mulani, N. and Cases, C., (2008). Mastering Global Operations in Multipolar World. Supply Chain Management Review, Mar2008, Vol. 12 Issue 2, p22-29.

18. Ding, Q., Dong, L. and Kouvelis, P., (2007). On the Integration of Production and Financial Hedging Decisions in Global Markets. Operations Research, Vol. 55, No. 3, May-June 2007, 470489.

19. Economy, E. and Lieberthal, K., (2007). Scorched Earth. Harvard Business Review, Jun 2007, Vol. 85 Issue 6, p88-96.

20. Faisal, M.N., Banwet, D.K. and Shankar, R., (2007). Information risks management in supply chains: an assessment and mitigation framework. Journal of Enterprise Information Management, Vol. 20 No. 6, 2007, 677-699.

21. Fang, F. and Whinston, A., (2007). Option Contracts and Capacity Management-Enabling Price Discrimination under Demand Uncertainty. Production and Operations Management, Vol. 16, No. 1, January-February 2007, 125-137.

22. Finch, P., (2004). Supply chain risk management. Supply Chain Management: An International Journal, Vol. 9 (2) 2004, 183-196.

23. Fitzgerald, K.R., (2005). Big Savings, But Lots of Risk. Supply Chain Management Review, Dec 2005, Vol. 9 Issue 9, p16-20.

24. Geary, S., Childerhouse, P. and Towill, D., (2002). Uncertainty and the Seamless Supply Chain. Supply Chain Management Review, Jul/Aug2002, Vol. 6 Issue 4, 52-61.

25. Giermanski, J.R., (2000). A "Black Hole" on the Border. Supply Chain Management Review, July/August 2000, 17-20.

26. Goh, M., Lim, J.Y.S. and Meng, F., (2007). A stochastic model for risk management in global supply chain networks. European Journal of Operational Research, 182 (2007) 164-173.

27. Handfield, R.B., Ragatz, G.L., Petersen, K.J. and Monczka, R.M., (1999). Involving Suppliers In New Product Development. California Management Review, Vol 42. No. 1, Fall 1999.

28. Hartley-Urquhart, R., (2006). Managing the Financial Supply Chain. Supply Chain Management Review, September 2006, 18-25.

29. Hauser, L.M., (2003). Risk-Adjusted Supply Chain Management. Supply Chain Management Review, Nov/Dec 2003, Vol. 7 Issue 6, 64-71. 
30. Hendricks, K.B. and Singhal, V.R., (2005). An Empirical Analysis of the Effect of Supply Chain Disruptions on Long-Run Stock Price Performance and Equity Risk of the Firm. Production and Operations Management, Vol. 14, No. 1, Spring 2005, 35-52.

31. Johnson, M.E., (2001). Learning from Toys: Lessons in Managing Supply Chain Risk From the Toy Industry. California Management Review, Vol 43, No. 3, Spring 2001.

32. Jüttner, U., (2005). Supply chain risk management: Understanding the business requirements from a practitioner perspective. The International Journal of Logistics Management, Vol. 16 No. 1, 2005, 120-141.

33. Kamrad, B. and Siddique, A., (2004). Supply Contracts, Profit Sharing, Switching, and Reaction Options. Management Science, Vol. 50, No. 1, January 2004, 64-82.

34. Kerr, J., (2006). Streamlining the Cash Flow. Supply Chain Management Review, October 2006, S25-S31.

35. Khan, O., Christopher, M. and Burnes, B., (2008). The impact of product design on supply chain risk: a case study. International Journal of Physical Distribution \& Logistics Management, Vol. 38 No. 5, 2008, 412-432.

36. Kirkwood, C.W., Slaven, M.P. and Maltz, A., (2005). Improving supply chain configuration decisions at IBM. Interfaces, Vol. 35, No. 6, November-December 2005, 460-473.

37. Kleindorfer, P.R. and Saad, G.H., (2005). Managing Disruption Risks in Supply Chains. Production and Operations Management, Vol. 14, No. 1, Spring 2005, 53-68.

38. Kouvelis, P., (1999). Global sourcing strategies under exchange rate uncertainty. Quantitative Models for Supply Chain Management, Eds. Tayur, S., Ganeshan, R. and Magazine, M.; International series in operations research \& management science; 17, Massachusetts: Kluwer Academic Publishers, 1999.

39. Kremic, T., Tukel, O.I. and Rom, W.O., (2006). Outsourcing decision support: a survey of benefits, risks, and decision factors. Supply Chain Management: An International Journal, 11/6 (2006), 467-482.

40. LaLonde, B.J., (2004). A Crisis in Transportation. Supply Chain Management Review, November/December 2004, 7-8.

41. LaLonde, B.J., (2000). The Cost of Switching. Supply Chain Management Review, March/April 2000; 11-12.

42. Lee, H.L., (2004). The Triple-A Supply Chain. Harvard Business Review, October 2004; 102112.

43. Lee, H.L., (2002). Aligning Supply Chain Strategies with Product Uncertainties. California Management Review, Vol 44, No. 3, Spring 2002. 
44. Lee, H.L., (2007). Have Your Cake*. Supply Chain Management Review, April 2007, Vol. 11 Issue 3, 26.

45. Levary, R.R., (2007). Ranking foreign suppliers based on supply risk. Supply Chain Management: An International Journal, 12/6 (2007) 392-394.

46. Li, L., Porteus, E.L. and Zhang, H., (2001). Optimal Operating Policies for Multiplant Stochastic Manufacturing Systems in a Changing Environment. Management Science, Vol. 47, No. 11, November 2001, 1539-1551.

47. Martínez-de-Albéniz, V. and Simchi-Levi, D., (2005). A Portfolio Approach to Procurement Contracts. Production and Operations Management, Vol. 14, No. 1, Spring 2005, 90-114.

48. Murphy, S., (2007). The Supply Chain in 2008. Supply Chain Management Review, December 2007; 4-7.

49. Nagurney, A., Cruz, J., Dong, J. and Zhang, D., (2005). Supply chain networks, electronic commerce, and supply side and demand side risk. European Journal of Operational Research, 164 (2005) 120-142.

50. Narayanan, V.G. and Raman, A., (2004). Aligning Incentives in Supply Chains. Harvard Business Review, Nov 2004, Vol. 82 Issue 11, 94-102.

51. Norrman, A. and Jansson, U., (2004). Ericsson's proactive supply chain risk management approach after a serious sub-supplier accident. International Journal of Physical Distribution \& Logistics Management, 34/5 (2004); 434-456.

52. Papadakis, I.S., (2006). Financial performance of supply chains after disruptions: an event study. Supply Chain Management: An International Journal, 11/1 (2006) 25-33.

53. Paulson, U., (2005). Developing a Supply Chain Flow Risk Model. NOFOMA 2005 Conference, Copenhagen, 9-10 June 2005.

54. Peck, H., Abley, J., Christopher, M., Haywood, M., Saw, R., Rutherford, C. and Strathern, M., (2003). Creating Resilient Supply Chains. Cranfield University, Cranfield School of Management, UK.

55. Peck, H., (2005). Drivers of supply chain vulnerability: an integrated framework. International Journal of Physical Distribution \& Logistics Management, Vol. 35 No. 4, 2005, 210232.

56. Peck, H., (2006). Reconciling supply chain vulnerability, risk and supply chain management. International Journal of Logistics: Research and Application, Vol. 9, No. 2, june 2006, 127-142. 
57. Pilkington, A., Meredith, J., (2009). The evolution of the intellectual structure of operations management - 1980-2006: A citation / co-citation analysis. Journal of Operations Management, Vol. 27, No. 3, 2009, 185-202.

58. Poirier, C.C., Swink, M.L. and Quinn, F.J., (2007). Global Survey of Supply Chain Progress. Supply Chain Management Review, October 2007; 20-27.

59. Quinn, F., (2006). Risky Business. Supply Chain Management Review, May/Jun 2006, Vol. 10 Issue $4,5-5$.

60. Raman, A., DeHoratius, N. and Ton, Z., (2001). The Achilles' Heel of Supply Chain Management. Harvard Business Review, May 2001, Vol. 79 Issue 5, 25-28.

61. Reichheld, F. F. and Schefter, P., (2000). E-Loyalty: Your Secret Weapon on the Web. Harvard Business Review, July/August 2000, 105-113.

62. Rice, J.B. and Caniato, F., (2003). Building a secure and resilient supply network. Supply Chain Management Review, Sep/Oct 2003, Vol. 7 Issue 5, 22-30.

63. Sheffi, Y. and Rice, J.B., (2005). A Supply Chain View of the Resilient Enterprise. MIT Sloan Management Review, Fall 2005, Vol. 47 Issue 1, 41-48.

64. Snyder, L.V., Daskin, M.S. and Teo, C.P., (2007). The stochastic location model with risk pooling. European Journal of Operational Research, 179 (2007) 1221-1238.

65. Sodhi, M.S., (2005). Managing Demand Risk in Tactical Supply Chain Planning for a Global Consumer Electronics Company. Production and Operations Management, Vol. 14, No. 1, Spring 2005, 69-79.

66. Sounderpandian, J., Prasad, S. and Madan, M., (2008). Supplies from developing countries: Optimal order quantities under loss risks. Omega, 36 (2008) $122-130$.

67. Spekman, R.E. and Davis, E.W., (2004). Risky business: expanding the discussion on risk and the extended enterprise. International Journal of Physical Distribution \& Logistics Management, Vol. 34 No. 5, 2004, 414-433.

68. Stalk, G., (2006). The Costly Secret of China Sourcing. Harvard Business Review, Feb 2006, Vol. 84 Issue 2, 64-66.

69. Svensson, G., (2002). A conceptual framework of vulnerability in firms' inbound and outbound logistics flows. International Journal of Physical Distribution \& Logistics Management, Vol. 32 No.2, 2002, 110-134.

70. Tang, C.S., (2006a). Perspectives in supply chain risk management. International Journal of Production Economics, 103 (2006) 451-488.

71. Tang, C.S., (2006b). Robust Strategies for Mitigating Supply Chain Disruptions. International Journal of Logistics: Research and Application, Vol. 9, No.1, March 2006, 33-45. 
72. Tapiero, C.S., (2007). Consumers risk and quality control in a collaborative supply chain. European Journal of Operational Research, 182 (2007) 683-694.

73. Tomlin, B., (2006). On the Value of Mitigation and Contingency Strategies for Managing Supply Chain Disruption Risks. Management Science, Vol. 52, No. 5, May 2006, 639-657.

74. van Putten, A.B., and MacMillan, I.C., (2004). Making Real Options Really Work. Harvard Business Review, Dec 2004, Vol. 82 Issue 12, 134-141.

75. Wagner, S. M. and Bode, C., (2006). An empirical investigation into supply chain vulnerability. Journal of Purchasing and Supply Management, 12 (2006) 301-312.

76. Wong, C.Y. and Hvolby, H.H., (2007). Coordinated responsiveness for volatile toy supply chains. Production Planning \& Control, Vol. 18, No. 5, July 2007, 407-419.

77. Wu, Y., (2006). Robust optimization applied to uncertain production loading problems with import quota limits under the global supply chain management environment. International Journal of Production Research, Vol. 44, No. 5, 1 March 2006, 849-882.

78. Yu, G., (1997). Robust Economic Order Quantity Models. European Journal of Operational Research, 100 (1997) 482-493.

79. Zhang, F., (2006). A note on supply risk and inventory outsourcing. Production Planning \& Control, Vol. 17, No. 8, December 2006, 796-806. 